\title{
第二言語学習ストレスに関する試論的研究 \\ PENELITIAN TERHADAP TINGKAT STRESS YANG DIALAMI OLEH PEMBELAJAR BAHASA ASING
}

\author{
河崎 絵美 \\ Kawasaki Emi \\ Japanese Department, Faculty of Language and Culture, Bina Nusantara University, \\ Jln. Kemanggisan Ilir III No. 45, Kemanggisan/Palmerah, Jakarta Barat 11480
}

\begin{abstract}
Article reveals the difference of stress among students and lecturers when they were studying in the class. However, I focused this research only in the second language class. The distinction of the stress will be shown on graphic. I used questionnaire to collect the data from the students and lecturers that I had mentioned above.

Keywords: stress, second language class, lecturer, students

ABSTRAK

Artikel menjelaskan perbedaan stress yang terjadi antara dosen dan mahasiswa ketika mereka berinteraksi di dalam kelas. Pelnelitian berfokus pada kelas pembelajajaran bahasa sebagai bahasa ke dua. Hasil analisis akan ditunjukkan mellaui grafik. Data penelitian diperoleh dari kuesioner yang disebarkan ke mahasiswa dan dosen.
\end{abstract}

Kata kunci: stres, kelas bahasa asing, dosen, mahasiswa 


\section{はじめに}

第二言語を学ぶ時、その言語の上達度が上級レベルであっても初級レベルであっても 、何らかの不安や緊張を感じるものである。しかし母語を普段の生活上で話す際は、その内 容や話す相手によって不安や緊張を感じるかもしれないが、特に性格的に神経質であるとか 、内向的で赤面症だとか言う場合は別として、それほど緊張はしないものである。例えば、 我々が英語や中国語などで話しをしょうとすると、何らかの不安やプレッシャーを感じる。 これを以後「第二言語ストレス」と呼ぶ。

本研究では大学の「外国語」授業において生じるストレスの有無について検証し、適 度な緊張感を持って効果的に第二言語を学ぶ方法を模索していく。

\section{研究目的}

日本で日本語を学習している学習者は、「異国で生活する」ということだけで、第二 言語ストレスだけでなく経済的な面や生活習慣において不安や緊張が高まり、多大なストレ スを感じていると考えられる。そこでまず、その点について「留学生の不安や緊張」につい て検証する。

第二言語学習者の多くは、第二言語の授業の前になると「授業中に当てられたらどう しょう。」「当てられて答えられなかったらどうしょう。」という不安に駆られていると推 測される。そして、その不安は緊張に繋がり、より一層授業に対するストレスは大きくなる のではないかと推測される。そして授業が終わると「当てられずに無事終わった。」「恥ず かしい想いをしなくて済んだ。」という安心感を抱き、授業前と比較すると、そのストレス は緩和されていると仮定される。例えば、英語で何かを伝えようとする、あるいは英語母語 話者に話しかけられた時、我々は極度に緊張が高まる。その場を何とか乗り切った後に、会 話の内容を振り返ってフィードバックをすると、あの場合はどういう応答が適切であったの か、相手は何を言っていたのか理解できるのに、実際に話している時は全く理解できず話せ ない。それは、おそらく過剩な緊張がSpeakingやListeningに大きく影響していると考えら れる。同じように、英語や中国語、ドイツ語、韓国語などの授業の前にも、平常時以上に学 習者の不安が高まり、緊張しているのではないかと考えられる。特に留学生の場合は、異国 の地で生活していることだけで第二言語ストレスを感じているだけに授業前ともなると、よ り一層不安が高まり、かなりの緊張感があると予想される。

本研究では、まず日本に来日している留学生を対象に、平時の不安水準を調へ、それ を日本人大学生の平時の不安水準とを比較し、留学生の緊張水準を明確にする。次に、中国 語の授業前・後の受講生の緊張水準を、韓国語の授業前・後の受講生の緊張水準と、更に日 本に来日している留学生が受講する「日本語」の授業前・後の緊張水準を調查し、第二言語 を学ぶ直前の緊張水準を明らかにし、第二言語ストレスの有無を検証する。

仮説 1。留学生は、日本で生活している母語話者（日本人）よりも不安が高い。

仮説 2 . (1)日本語、(2)中国語、(3)韓国語といった第二言語学習の授業前には、緊張（不 安）水準が高くなる。 


\section{研究方法}

\section{被験者}

姫路獨協大学 姫路獨協大学 姫路獨協大学 姫路独協大学
留学生

韓国語履修者

中国語履修者

教職課程履修者
合計 13 名（男6名、女 7 名）

合計 14 名（男6名、女8名）

合計 13 名（男6名、女7名）

合計 59 名（男26名、女33名）

期日 2005年12月1日から2006年1月18日

\section{質問紙［不安測定用紙]}

新版 S T A I （State-Trait Anxiety Inventory-Form JYZ）；実務教育出版社発行

S T A I I : 状態不安

S T A I II : 特性不安

緊張度 : 授業前状態不安 - 授業後状態不安 $=$ 緊張水準

このS T A I テストは被験者の母語に中国語母語話者・韓国語母語話者に訳してもらい、 被験者に回答してもらった。

\section{手続き〔教示]}

〈授業前〉（日本語・中国語・韓国語）の授業前に「この自己評価テストは（日本語・中国 語・韓国語）の成績に関係しません。このテストは、今後の授業の改善のための ものです。率直に今の気持ちに当てはまる番号に○をしてください。」と説明し て記入してもらった。

〈授業後〉（日本語・中国語・韓国語）の授業終了後に「授業前のテストと同じものですが 、今現在の率直な気持ちに当てはまるものに○をしてください。」と説明し記入 してもたった。

\section{結果と考察}

日本語・中国語・韓国語のそれぞれの授業前と授業後における各群の授業前不安水 準、各群の授業後不安水準、各群の緊張度、および各群の特性不安の結果をFig. 1-1, 1-2 Fig. 2-1, 2-2, 2-3, 2-4, 3-5, 3-6 Table. 1-1, 1-2, 1-3に示す。

仮説 1 の結果と考察（留学生の不安水準（日本人学生との比較））

留学生は慣れ親しんだ母国を離れ異国の言語、つまり第二言語を使用し、その国の生活 習慣を理解して生活しなくてはならないという状況から、日本人に比べて不安や緊張が高く 、そのストレスが高いことが予想された。しかし、調查結果からすると状態不安ではその差 は有意ではなかった。また、特性不安については日本人の方が不安水準が高いという結果が 示された。 
Table 1日本人と留学生の状態不安と特性不安

\begin{tabular}{lcccc}
\hline & \multicolumn{2}{c}{ 日本人 } & \multicolumn{2}{c}{ 留学生 } \\
\hline & 状態不安 & 特性不安 & 状態不安 & 特性不安 \\
不安水準 & 44.6 & 52.1 & 44.2 & $48.2 *$ \\
標準偏差 & 8.37 & 7.86 & 6.68 & 3.85 \\
\hline
\end{tabular}

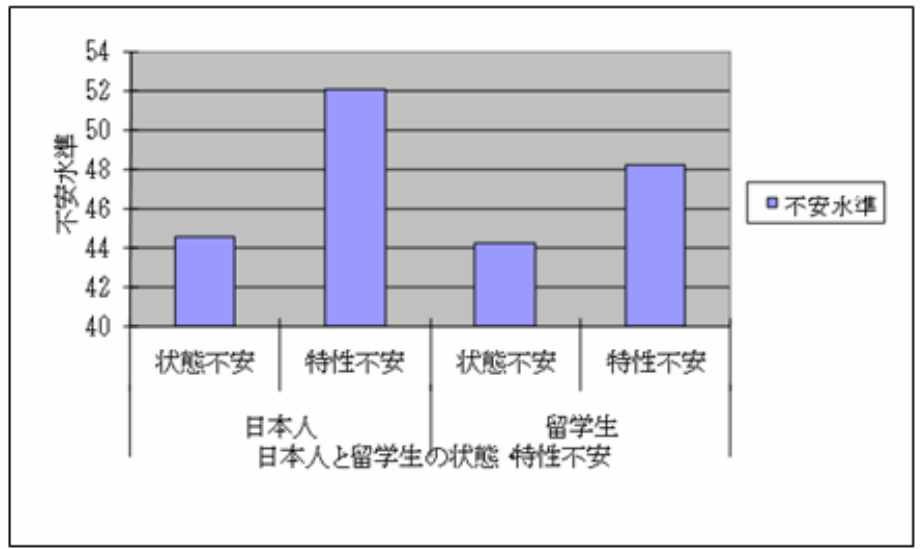

Figure 1 日本人上留学生O伏態 +特性不宽水隼

日本人学生の状態不安は不安水準が 44.6 であるのに対し、留学生は 44 、特性不安にお いては52.1に対し、留学生は48．2であった。これらの結果は、予測とは異なる結果とな った。この結果を通し、留学生は日本語を本当に学びたいという強い熱意と、親元を遠く離 れ開放感を感じていることから日本での生活を愉しみ、更に必要となるコミュニケーション 能力の向上のために、日本語の学習を生活の中の一つとして捉えていることから、このよう な結果となったと思われる。

一方、日本人学生の場合、特性不安おいて留学生の不安水準を上回る結果であった。 これは日本人の授業に対するストレス（不安）が大きく関係していると予測される。特に、 特性不安においては教職課程を履修していることから将来への期待が大きい反面、明確では ない将来へ不安を抱いている学生が多いのではないかと予測される。その不安が授業に取り 組む姿勢に緊張感を与え、授業についていけるか、テストに今日の授業内容が出るのではと いうストレスを感じさせていると予測される。また、特性不安においては学費や生活費のた めにアルバイトをしているなどという経済的理由から、常に不安と隣り合わせの状況にある ためストレス（不安・緊張）を感じる日々を送っているのではないかと推測される。

仮説 1 の結果と考察（日本、中国語、韓国語の授業を受ける際の不安水準）

(1)日本語

授業前の不安水準が44、授業後の不安水準が42であった。緊張度は2である。日本語の 授業において授業前と後の不安の評定平均值の差の検定をした結果、両群に有意差が認めら れた。 


\begin{tabular}{|c|c|c|}
\hline 日本語 & 授業前 & 授業後 \\
\hline 不安水準 & 44.16327 & 41.5051 \\
\hline 標本標準偏差 & 6. 419372 & 5. 229915 \\
\hline
\end{tabular}

* $: \mathrm{P}<.0 .05 * *: \mathrm{P}<.0 .1$

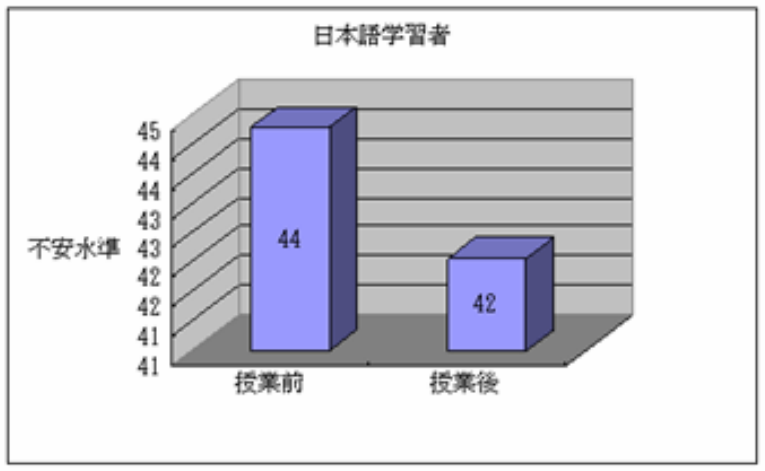

Figure 2 文業前後の不安

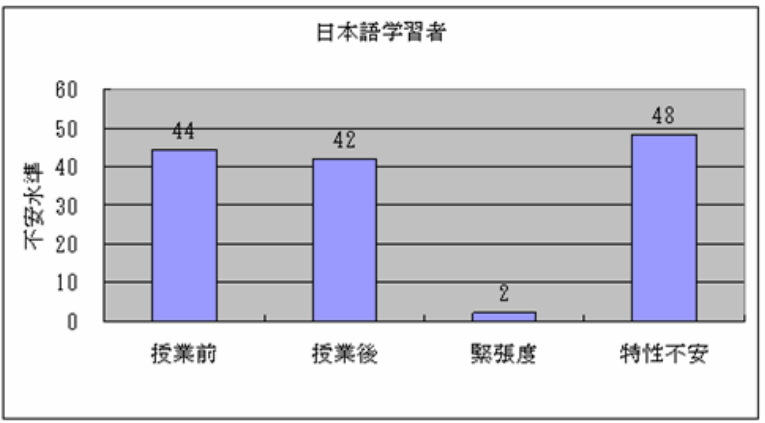

Figure 3 授業前 後、緊張度、不安特性

(2)中国語

授業前の不安水準が50、授業後の不安水準が46であった。緊張度は 4 である。中国語 の授業において授業前と後の不安の評定平均值の差の検定をした結果、両群に有意差が認め られた。

Table 3 授業前・後の不安水準

\begin{tabular}{|c|c|c|c|}
\hline 中国㣎 & 授業前 & 授業後 & 小 \\
\hline 不家水準 & 50.38462 & 44.92308 & $* \quad: \mathrm{P}<0.05$ \\
\hline 標本標準痌差 & 8.588155 & 7.088271 & $* *: \mathrm{P}<0.1$ \\
\hline
\end{tabular}




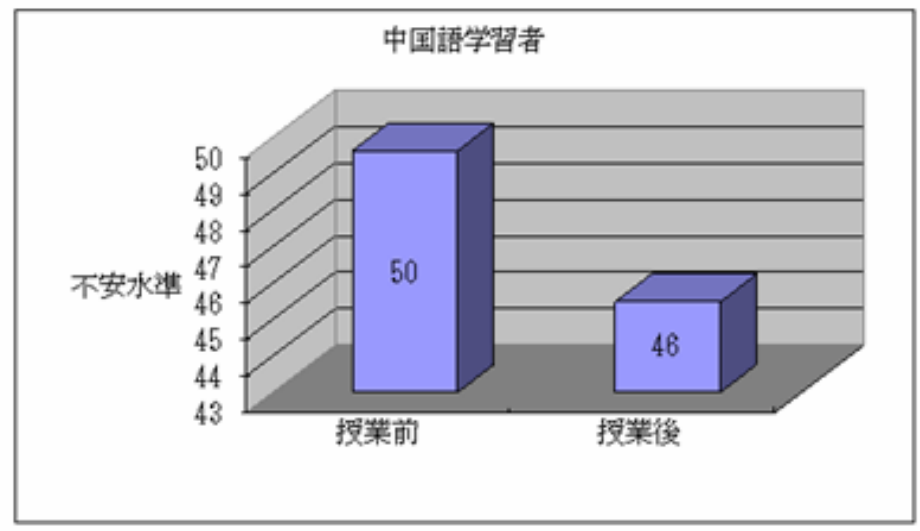

Figure 4 投業前・後の不安

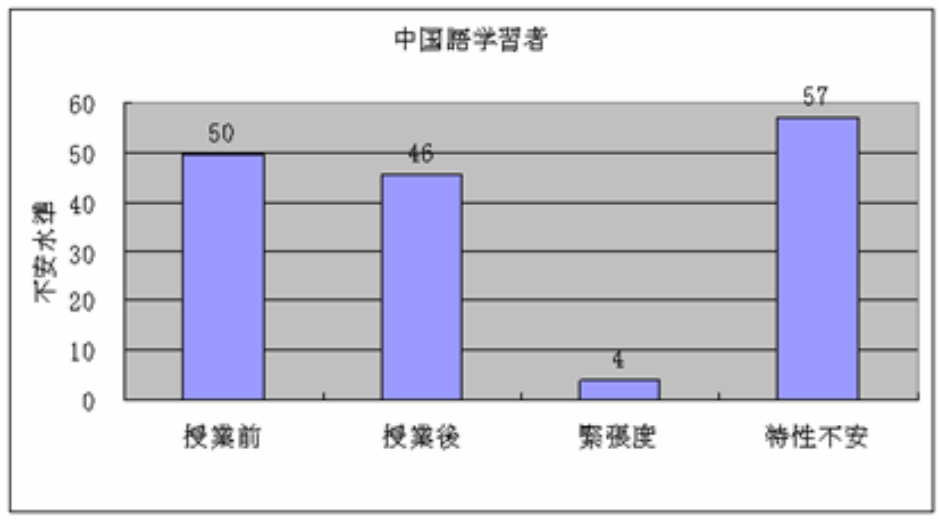

Figure 5 投業前 後の不安、箱張度、特性不安

(3)韓国語

授業前の不安水準が49、授業後の不安水準が45であった。緊張度は 4 である。韓国語 の授業において授業前と後の不安の評定平均值の差の検定をした結果、両群に有意差が認め られた。

Table 4 授業前 後の不安

\begin{tabular}{|c|c|c|c|}
\hline 靼国語 & 授業前 & 授業啳 & * \\
\hline 不富水準 & 49.57143 & 44.07143 & * $\quad: \quad \mathrm{F}<0.05$ \\
\hline 標本標準惼差 & 12.62302 & 13.27499 & $* * 2: P<0.1$ \\
\hline
\end{tabular}




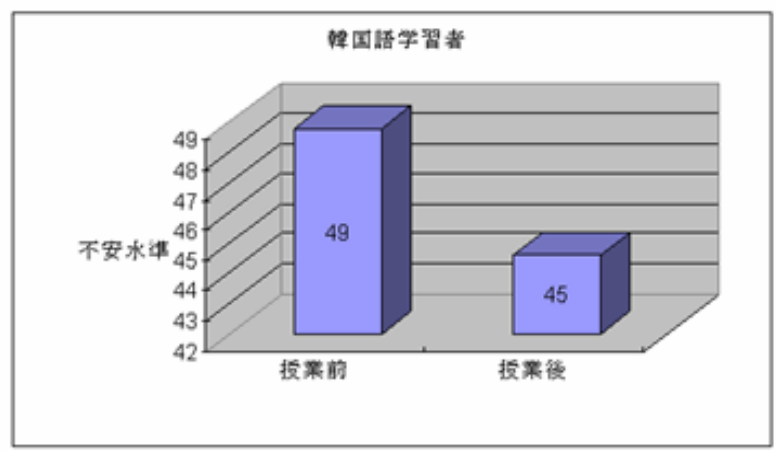

Figure 6 援莱韵・镂の不安

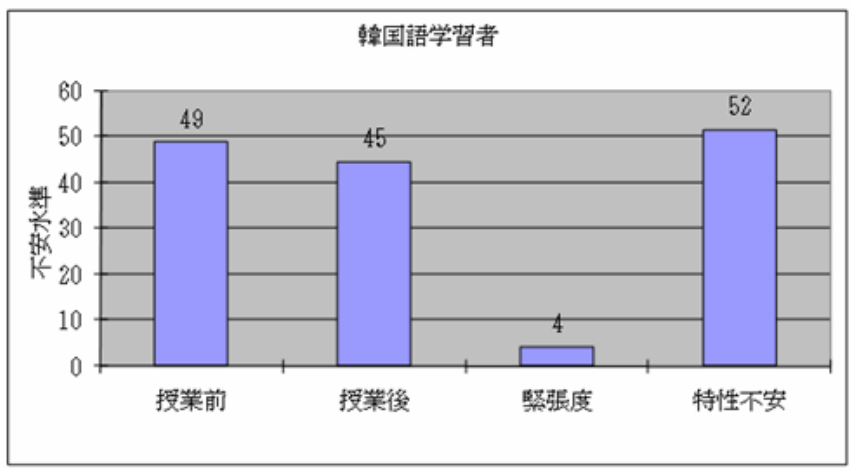

Figure 7 投業前 後、緊張度、特性不安

以上のデータから、(1)日本語(2)中国語(3)韓国語のいずれの第二言語学習時においても 授業前に、何らかの不安や緊張を感じていることが明確となり、「第二言語ストレス」の存 在が検証された。

この第二言語ストレスには「フラストレーション」が存在する。このフラストレーシ ヨンとは、「目標追求活動をさえぎり、動機の充足を妨げること、およびその結果として生 じる情緒状態をいう。」（村田1987；84）一方、「ストレス」とは「外界からのあらゆる欲 求によってもたらされる生体の特異的な反応」（荒木・倉戸2003；2）とセリエ（Selye, H, ）によって最初に提唱された。この $2 つ の$ 関連性は強く、人間が何かの目標（動機）を持っ て行動している時、例えば中国に行きたい、韓国に住みたいというような何らかの憧れから 中国語、韓国語を学ぼうという動機付けが起こる。こういった動機が何らかの形で妨害され た場合、例えば、どんなに一生懸命単語を覚えてもネイティブ話者を前にして、実際に覚え た単語を使って話そうとしてもうまく言いたいことが相手に伝わらない、というコミュニケ ーションの不成立が起こると、忽ちフラストレーションを感じる。なぜなら、我々人間は何 事においても一回の学習でプロのようなレベルまで達することはないからである。例えば、 ピアノを習い始めたころは旨く指が動かなくてイライラ寸る。しかし、何度も繰り返し練習 していくうちに、以前より上達していることに気がつく。そして、更なる向上を目指し練習 を重ねるが、ある一定の水準までいくと、そこから上へ更に向上させるには大きな波がいく つも待ち構えている。その波はスランプの時期にあり、その時期を乗り越えなければ更なる 上達は望めないのである。このスランプ時に感じる感情が、フラストレーションでありスト レスである。 
調査を行った時期が 1 年間の終わりの時期であったため、留学生においては、日本の 生活や文化にも慣れ始め、またそれを受け入れ始めた時期である。また、他の被験者におい ても 1 年の授業の終わりということで、ある程度、授業内容・方針を理解していることが予 想される。以上の結果から、今後の課題として挙げられることに、日本に来日して間もない 日本語学習者、大学に入学して間もない第二言語学習者の第二言語ストレスについて調査を 実施し、第二言語ストレスの負担度を 1 年間第二言語を学習している被験者と比較し、その 差を検証してみることが求められる。

\section{総括}

第二言語を学習する際、やはり「第二言語ストレス」を学習者は感じていることが今 回のS T A I テストの結果から明らかとなった。人間が学習をする際、不安や緊張の值が高 すぎると、また全く学習に対して不安も緊張も感じない低い值であると、それは学習に適し た心的状態であるとは言えない。学習をする際は、適度な緊張感を持って取り組むことが、 その目標をより早く更に効果的に習得する近道となるのである。これは「ヤーキンス・ダト ソンの法則」で説明されていることである。

この様に、第二言語を習得する場合に学習者が第二言語ストレスを感じていることが 明らかとなったが、教師にとっても、このストレスの存在が左右されている可能性が考えら れる。教師は学習者の、この言語ストレスの存在を理解し、授業クラスの雾囲気作りや学習 者のパーソナリティーを考慮した学習項目・展開を行う必要がある。しかし、これに関して は今後、更なる研究求められる。

引用文献

村田考次 1987 『教養の心理学』培風館

荒木紀幸・倉戸ツギオ2003『健康とストレス・マネジメントー学校生活と社会生活の充実に むけて』ナカニシヤ出版 